\title{
Organic matter dynamics in a savanna transition riparian zone: Input of plant reproductive parts increases leaf breakdown process
}

\author{
Renan S. REZENDE, ${ }^{1,2^{*}}$ Patrícia R.S. CORREIA, ${ }^{3}$ José F. GONÇALVES Jr, ${ }^{2}$ Anderson M. SANTOS ${ }^{3}$
}

${ }^{1}$ Program of Postgraduate in Ecology and Conservation, Federal Rural University of the Semi-arid Region, 59.625-900 Rio Grande do Norte; ${ }^{2}$ Department of Ecology, Institute of Biology, University of Brasilia, 70910-900 Brasília, Federal District; ${ }^{3}$ Department of Biology, Institute of Biological Sciences, State University of Montes Claros, 39401-089 Montes Claros, Minas Gerais, Brazil

*Corresponding author: renanrezende30@gmail.com

\begin{abstract}
The dynamics of coarse particulate organic matter (CPOM) drives the functioning of most low order freshwater ecosystems. We evaluated plant litter input, litterfall, leaf litter breakdown rates, and the aquatic invertebrate community over the course of one year in a stream situation in a transition zone between savannah and Atlantic forest. Total organic matter input (litter fall) was 335 $\mathrm{g} \mathrm{m}^{-2} \mathrm{yr}^{-1}$, which was mainly composed of leaves (50\%). Higher values are found in the transition from dry to rainy season (September and October), probably in response to water stress. The remaining leaf mass (65\% on average) was lowest in May (49\%) and highest in August (79\%). CPOM productivity in this transition riparian zone is higher than in other savannah systems, but lower than in Atlantic forest. The higher leaf litter breakdown in May was likely accompanied by environmental enrichment due to increase in fruits and flowers (high energy resources). The coefficient of decomposition was classified as fast $(\mathrm{k}=-0.016)$ and showed a positive relationship with water flow (increase in physical abrasion). Collected invertebrates were classified as $6 \%$ shredders and $12 \%$ scrapers. The remaining leaf mass showed a negative relationship with scraper abundance, highlighting the importance of these trophic groups in tropical streams. We can conclude that climate factors (e.g., rainfall) directly affect the input and quality of CPOM and, consequently, leaf decomposition in savanna/Atlantic forest transition zones.
\end{abstract}

Key words: Decomposition; input of organic matter; mixing of leaves; scraper; shredders; vertical input.

Received: November 2016. Accepted: April 2017.

\section{INTRODUCTION}

Riparian vegetation represents a transition zone between terrestrial and aquatic ecosystems (Naiman et al., 2005; Tank et al., 2010). Riparian zones display ecological functions such as bank stabilization, water control (quality and quantity), organic matter (OM) input, and conservation of biological diversity (Allan, 2004; Allan and Castillo, 2007). The vegetation in these areas also serves as a source of energy for aquatic ecosystems by providing allochthonous OM (Webster and Meyer, 1997; Tank et al., 2010). The input of coarse particulate organic matter (CPOM) accounts for approximately $90 \%$ of the allochthonous OM in headwater streams (Campbell et al., 1992), mainly in closed canopy areas, by decreasing photosynthetic production (Tank et al., 2010; Graça et al., 2015). Evaluation of CPOM throughout the year is thus important for understanding OM cycling in riparian zones (Abelho, 2001), mainly in tropical streams (Rezende et al., 2016). Studies addressing ecological processes in tropical streams have emerged only in the last decade (Gonçalves et al., 2006a; França et al., 2009; Lisboa et al., 2014; Rezende et al., 2016).

CPOM fractions (leaves, flowers, fruits, and branches) are transformed to fine particulate organic matter (FPOM) and later into dissolved organic matter (DOM) by decomposing organisms (Gessner et al., 1999; Graça et al., 2015). The mineralization of OM by decomposition is a continuous process in trophic webs, which can be influenced by biotic and abiotic factors (Gessner et al., 1999; Graça et al., 2015). For example, higher water nutrient concentrations can increase the rate of leaf litter breakdown by increasing the activity of decomposers (Gonçalves et al., 2007; Rezende et al., 2014). Chemical characteristics of the leaf litter also impact organic matter dynamics and nutrient cycling in these environments (Wantzen et al., 2008; Rezende et al., 2014; Graça et al., 2015). Leaf litter with higher concentrations of secondary compounds (e.g., polyphenols), structural compounds (e.g., lignin and cellulose), and hardness can decrease litter quality and breakdown rates (Wantzen et al., 2008; Rezende et al., 2014; Graça et al., 2015).

Fungi, bacteria, and benthic invertebrates are the main decomposer organisms in the transformation of CPOM to FPOM and DOM (Gessner et al., 1999; Graça, 2001; Graça et al., 2015). Aquatic fungi (e.g., hyphomycetes) can mineralize litter through enzymatic action, driving the breakdown of structural and recalcitrant compounds (e.g., 
lignin and cellulose). On the other hand, bacteria decompose labile molecules (e.g., secondary metabolites), manly in the initial stage of this process (Gessner et al., 1999; Graça, 2001; Graça et al., 2016). Microbial communities are also responsible for the nutritional enrichment of litter, increasing palatability and facilitating litter use by benthic macroinvertebrate shredders and scrapers (Graça et al., 2015; Sales et al., 2015). Although some tropical streams have high density and richness of shredders (Cheshire et al., 2005; Allan et al., 2009), most studies report low numbers (Boyero et al., 2011, 2012; Rezende et al., 2015) compared scrapers, which function in leaf fragmentation by consuming periphyton in these systems (Wantzen and Wagner, 2006; Gonçalves et al., 2012a).

In South American savanna streams, litterfall occurs mainly in the dry season due to hydrological stress (Gonçalves and Callisto, 2013; Gonçalves et al., 2014a). Leaf litter breakdown may vary throughout the year, stimulated by increases in temperature (higher metabolism in the system), density of decomposer communities (microorganisms and invertebrates), nutrient concentrations (manly nitrogen and phosphorus), and water flow (fiscal abrasion) (Gonçalves et al., 2014b; Graça et al., 2016). However, the majority of tropical studies evaluate only i) specific species of litter; ii) specific sample periods (60 to 90 days, manly in dry season); and iii) leaves collected outside of the riparian vegetation of the study stream. This methodological approach may negligence the high species number in tropical riparian zones and the mixing effects on the leaf litter input and breakdown in this system (Gessner et al., 2010).

Only two studies have been carried out in tropical streams, which measure aggregate leaf litter breakdown and litter fall input over the course of one year (Sales et al., 2015; Rezende et al., 2016). According to Rezende et al. (2016), this approach produces results that are more realistic in terms of measurement of litter breakdown, as they reflect seasonal variation in litter quality throughout the year. Another interesting aspect that has not been previously investigated is riparian zone litter dynamics in transition biomes (e.g. savannah and rainforest). Our hypotheses were constructed based on tropical studies of leaf litter breakdown and litter fall(Sales et al., 2015; Rezende et al., 2016), and in the transition characteristic of studied riparian zone, as follows: i) the total CPOM input will be higher than savanna riparian zones (less productive by lower rainfall), but lower than Atlantic rainforest (more productive due to higher rainfall); ii) the CPOM will peak during the transition from dry to rainy season (due to hydric stress and mechanical removal by rain); and iii) seasonal changes will accelerate leaf breakdown in rainy season due to increase in physical abrasion and decomposer community activity (higher metabolisms). This study aims to describe the litter input and leaf breakdown of allochthonous CPOM over one year in a savanna stream.

\section{METHODS}

\section{Study area}

The study was conducted in the Boleiras stream (first order) in the Rio Preto State Park, Minas Gerais, Brazil (18 $\left.07^{\prime} 04^{\prime \prime} \mathrm{S}-43^{\circ} 20^{\prime} 42^{\prime \prime} \mathrm{W}\right)$. The stream is located in the upper region of Jequitinhonha Valley in the Espinhaço Mountain complex, which has an average altitude of 800 meters. The climate regime is a tropical AW (with a dry winter), with a rainy season from November to March (average rainfall $223 \mathrm{~mm}$ ) and a dry season from June to August (average rainfall $8 \mathrm{~mm}$; http://hidroweb.ana.gov.br/).

\section{Input of organic matter}

Litterfall was measured monthly from January to December 2012. We selected 5 sampling points spaced 20 meters apart, for a total length of 100 meters along the stream (for details, see Sales et al., 2015; Rezende et al., 2016). The litter directly entering the stream (vertical input, VI) was measured at each sampling point using 3 rows of 6 buckets each $\left(0.53 \mathrm{~m}^{2}\right)$ (i.e., a total of 18 buckets per point at 5 points $=90$ replicates) suspended $2 \mathrm{~m}$ above the stream with ropes, which were transversely displayed in 5 rows (points were used as replicates: 5 points $\mathrm{x} 11$ months $=55$ replicates). The bucket bottoms were perforated to allow rainwater to evacuate. At monthly intervals, accumulated litter in the buckets was retrieved and weighed in situ (wet weight), and the contents of the bucket with the highest leaf litter mass in each row was used for the leaf litter breakdown experiments (see below). The contents of the remaining buckets ( 5 buckets in each row, which were not used in the leaf litter breakdown experiment) were oven dried to a constant mass $\left(60^{\circ} \mathrm{C}, 72 \mathrm{~h}\right)$, and the resulting weight was used as a correction factor to estimate the moisture of the litter used in the leaf litter breakdown experiment. The dry material was separated into the following categories: leaves, branches, reproductive material (flowers and fruits), and 'miscellaneous' (unidentified particulate organic matter).

\section{Leaf litter breakdown and aquatic invertebrates}

For this analysis, we used the leaves from the vertical input that were collected in 15 buckets above the stream; the leaves were weighed and placed in 15 litter bags (30 $\times 30-\mathrm{cm}$, with a $10-\mathrm{mm}$ mesh), and submerged (leaf litter from one bucket for one litter bag) in the stream for 30 days (until the next sampling period). The amount of material placed in the bags ranged from 1 to $3 \mathrm{~g}$ (litter bags having different sample weight due to monthly changes 
in litterfall throughout the year), and after one month, the leaf litter samples were removed and replaced with new ones (for additional information, see Sales et al., 2015; Rezende et al., 2016). The collected litter bags were transported to the laboratory in a cooler. According to Rezende et al. (2016), the use of bulk litter instead of leaves from known species better reflects decomposition at a site, representing a more realistic measurement of litter breakdown by accounting for seasonal variation in litter quality.

The remains of the leaf litter were washed with distilled water over a $250 \mu \mathrm{m}$ sieve in the laboratory, and the collected invertebrates were fixed in $70 \%$ ethanol. Invertebrates were later identified to family and genus, and classified into functional trophic groups as follows: gathering-collectors, filtering-collectors, shredders, scrapers, and predators, according to Hamada et al. (2014), Pérez (1988), Merritt and Cummins (1996), and (Cummins et al., 2005). Leaf discs (12 mm diam.) were removed with a cork borer from five randomly selected leaves, and the 5 discs were used to determine ash-free dry mass (AFDM; for correction of inorganic compounds). We calculated the AFDM by subtracting the ash weight (muffle in $750^{\circ} \mathrm{C}$ for $4 \mathrm{~h}$ ) from dry weight. The remaining leaf litter was placed in aluminum trays and dried in an oven at $60^{\circ} \mathrm{C}$ for $72 \mathrm{~h}$ to determine dry weight. Due to the high water flow and safety concerns during litterbag installation, the leaf breakdown experiment could not be performed from January to March.

\section{Physical and chemical parameters of water and leaf litter}

A multianalyzer (model 85, YSI Inc., Yellow Springs, $\mathrm{OH}$, USA) was used to measure in situ temperature $\left({ }^{\circ} \mathrm{C}\right)$, electrical conductivity $\left(\mu \mathrm{S} \mathrm{cm} \mathrm{cm}^{-1}\right), \mathrm{pH}$ (measured using YSI's EcoSense pH100A), and dissolved oxygen $\left(\mathrm{mg} \mathrm{L}^{-1}\right)$. On each sampling occasion, we measured current velocity $\left(\mathrm{m} \mathrm{s}^{-1}\right.$ ) using a flow meter (Sigma Sports model FP101, Global Water Instrumentation, Inc., Gold River, CA, USA), and the depth and width of the stream with measuring tape. Rainfall and air temperature data (mean values for the entire month) were obtained from a meteorological station (number 1843015) of the National Water Agency of Brazil (http://hidroweb.ana.gov.br/).

Total polyphenol and tannin concentrations were estimated per $100 \mathrm{mg}$ of leaf litter as proposed by Bärlocher and Graça (2005) and Graça and Bärlocher (2005), respectively. Phenolic concentrations were estimated per leaf after 30 days of incubation. The initial concentration per leaf was not measured for the breakdown experiment.

\section{Statistical analyses}

We are describing a case study (in a single stream) and therefore, the results and inference only relate to this stream. All analyses were performed in R version 3.3.0. Data normality was assessed with a Kolmogorov-Smirnov test, and homogeneity of variance was assessed with Levene's test; values were $\ln (+1)$ transformed if necessary. Differences in litterfall between the vertical inputs (points as replicates) and the inputs (response variables) over time (explanatory variable) were analyzed by repeated-measures ANOVA (RM-ANOVA; Crawley, 2007), and a contrast analysis was used to assess differences among months (Crawley, 2007). In this contrast analysis (orthogonal), the months were ordered by increasing input values and tested in a pairwise fashion (with the months with the closest values). Stepwise model simplification was performed by sequentially adding monthly values that did not affect the model, and testing against the next month in the sequence (for more details, see chapter 9 in Crawley, 2007).

Monthly leaf litter breakdown rates $(k)$ were obtained from a model assuming negative exponential mass loss during the 30 days of incubation $\left(W_{t}=W_{0} e^{-k t}: \mathrm{Wt}=\right.$ remaining weight; $\mathrm{W}_{0}=$ initial weight; $-k=$ decay rate; $\mathrm{t}=$ time). RM-ANOVAs and contrast analyses were used to test for significant differences among months (explanatory variable) in the remaining mass in the litter bags, and the abundances of scrapers and shredders (response variables). The average values of 5 points along the stream were used as repeated measures (over the months). A oneway ANOVA was used to test phenol and tannin concentrations (dependent variable) over the months (explanatory variables) (Crawley, 2007), and associations between variables were assessed using a Spearman's correlation test (Crawley, 2007). A multiple linear regression was used to evaluate relationships between remaining mass and climate variables (air temperature and precipitation), physical and chemical water properties (dissolved oxygen, conductivity, $\mathrm{pH}$, current speed, and water flow), the decomposer community (scrapers and shredders), and chemical characteristics of leaves (initial tannins, and initial and final phenols) (Crawley, 2007). In multiple linear regression, the beta coefficients represent the independent contributions of each independent variable to the prediction of the dependent variable. This type of correlation is also referred to as a partial correlation.

\section{RESULTS}

\section{Water and leaf litter physical and chemical parameters}

Rainfall during the study period was low (mean of $10 \pm 37 \mathrm{~mm}$; Fig. 1) with peaks in January and November. The average annual flow rate was $0.25 \mathrm{~m}^{3} \mathrm{~s}( \pm 0.1)$, and water temperature ranged from 18 to $22^{\circ} \mathrm{C}$, with air temperature ranging from 16 to $23^{\circ} \mathrm{C}$. The water stream was circumneutral, with low electrical conductivity but high 
levels of dissolved oxygen (Tab. 1). The average concentrations of secondary compounds were $5 \%$ tannins and $11 \%$ phenols for total litter mass throughout the year. Higher leaf litter tannin concentrations (12\%) were observed in August (ANOVA; $\mathrm{F}_{(8,85)}=3.56 ; \mathrm{P}=0.001$ ), but the concentration of phenols did not change over time (ANOVA; $\mathrm{F}_{(8,85)}=1.85, \mathrm{P}=0.078$ ).

\section{Organic matter input}

Total OM input (litterfall) over the 11-month study pe-

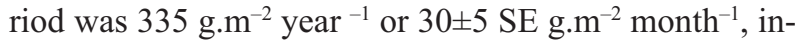
dicating an annual average of $360 \pm 5 \mathrm{~g} \cdot \mathrm{m}^{-2}$ year $^{-1}$. Leaf litter was the OM category with the highest annual contribution (50\%) and two input peaks, one in April and another in September and October (Tab. 2; Fig. 2). The lowest values occurred in the dry season from June to August. Branches had the second largest contribution $(31 \pm 3 \%)$, with an input peak in November that coincided with higher rainfall (Tab. 2; Fig. 2). Flowers and fruits contributed $18 \%( \pm 1)$ of the total OM, with an input peak in May (Tab. 2; Fig. 2). Miscellaneous OM made the smallest contribution with $2 \%( \pm 1)$, which did not change throughout the year. Branches positively correlated with rainfall $(\mathrm{r}=0.63, \mathrm{P}=0.03)$, but there were no significant correlations among any other categories of OM input with either rainfall or air temperature $(\mathrm{P}>0.05)$.

\section{Leaf litter breakdown rates}

The average remaining mass was $65 \%( \pm 3)$ over the year, with lower values in May (49\%) and higher values in August (79\%). The mean decomposition coefficient (" $k$ ") was -0.016 , ranging from -0.008 (August) to -0.029
(May). Similar to that observed for vertical input litterfall, the remaining leaf mass showed a bimodal distribution with two peaks, the first in August and the second in November and December (Tab. 2; Fig. 3). The remaining mass (adjusted $\mathrm{R}^{2}=0.76, \mathrm{~F}_{(3,5)}=7.44 ; \mathrm{P}=0.03$ ) showed a positive relationship with water flow $($ Beta $=0.70)$ and water temperature (Beta $=0.38)$, but a negative relationship with scraper abundance (Beta $=-0.42$ ). The remaining mass was not affected by the other variables tested.

\section{Aquatic invertebrate communities}

The density of invertebrates that colonized the leaf litter ranged from 260 (October) to 9 individuals $\mathrm{g}^{-1}$ (November),

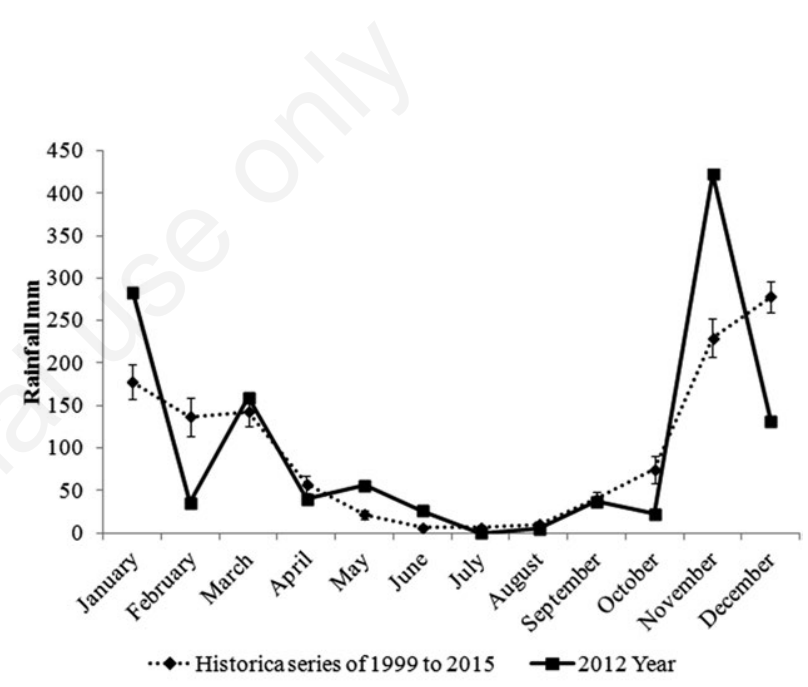

Fig. 1. Monthly values (total $\pm \mathrm{SE}$ ) for historical rainfall from 1999 to 2015 , and in 2012.

Tab. 1. Dissolved oxygen (DO), electrical conductivity (cond.), water temperature (WT), pH, current velocity (WV), water flow, air temperature (AT) and total precipitation (rainfall) in the Boleiras stream (January to December 2012).

\begin{tabular}{|c|c|c|c|c|c|c|c|c|}
\hline Month & $\begin{array}{c}\mathrm{DO} \\
\left(\mathrm{mg} \mathrm{L}^{-1}\right)\end{array}$ & $\begin{array}{c}\text { Cond } \\
\left(\mu \mathrm{S} \mathrm{cm}{ }^{-1}\right)\end{array}$ & $\begin{array}{l}\text { WT } \\
\left({ }^{\circ} \mathrm{C}\right)\end{array}$ & $\mathrm{pH}$ & $\begin{array}{l}\text { WV } \\
\left(\mathrm{m}^{-1}\right)\end{array}$ & $\begin{array}{l}\text { Flow } \\
\left(\mathrm{m}^{3} \mathrm{~s}^{-1}\right)\end{array}$ & $\begin{array}{l}\text { AT } \\
\left({ }^{\circ} \mathrm{C}\right)\end{array}$ & $\begin{array}{c}\text { Rainfall } \\
(\mathrm{mm})\end{array}$ \\
\hline January & - & - & - & - & - & - & 20.35 & 346.90 \\
\hline February & - & - & - & - & - & - & 20.80 & 44.60 \\
\hline March & - & - & - & - & - & - & 20.55 & 127.90 \\
\hline April & 8.03 & 3.72 & 21.68 & 5.10 & 0.22 & 0.08 & 20.65 & 41.70 \\
\hline May & 8.27 & 3.38 & 19.26 & 6.01 & 0.19 & 0.11 & 18.15 & 66.30 \\
\hline June & 9.82 & 3.18 & 18.08 & 6.14 & 0.25 & 0.12 & 18.10 & 19.80 \\
\hline July & 9.12 & 3.02 & 15.96 & 6.01 & 0.26 & 0.13 & 17.10 & 2.70 \\
\hline August & 13.84 & 3.16 & 19.44 & 6.16 & 0.16 & 0.09 & 16.00 & 12.10 \\
\hline September & 10.03 & 3.91 & 21.19 & 6.65 & 0.17 & 0.10 & 19.60 & 17.40 \\
\hline October & 6.22 & 4.66 & 22.92 & 6.51 & 0.09 & 0.06 & 20.65 & 52.70 \\
\hline November & 5.14 & 16.08 & 22.62 & 6.23 & 0.76 & 1.48 & 20.10 & 362.20 \\
\hline December & 5.60 & 11.65 & 22.81 & 6.22 & 0.18 & 0.10 & 22.80 & 112.30 \\
\hline Mean & 8.45 & 5.86 & 20.43 & 6.11 & 0.25 & 0.25 & 19.57 & 100.55 \\
\hline
\end{tabular}


averaging 117 ( $\pm 9 \mathrm{SE})$ ind $\mathrm{g}^{-1}$. The average richness over the year was 10, and was lowest in November ( 2 taxa) and highest in October (15 taxa). During the study period, 10,038 invertebrates were collected that were associated with leaf litter, with the most abundant taxa being Tanypodinae $(25 \%)$, Chironominae (19\%), and Orthocladiinae $(16 \%)$ in the family Chironomidae (Diptera), which represented $60 \%$ of the collected individuals.

Only $6 \%$ of all invertebrates were classified as shredders, with the highest values observed in August (12\%) and November (13\%) (Tab. 2; Fig 3). The shredder trophic functional group was represented by Triplectides sp., Notalina sp., Marilia sp., Phylloicus sp. (Trichoptera), Paragripopteryx sp. (Plecoptera) and Hyalella sp. (Crustacea;
Tab. 3). The total relative abundance of scrapers was twice more $(12 \%)$ than that of shredders, with significantly higher values in July (18\%) compared to other months (Tab. 2; Fig. 3). The 'scraper' trophic functional group was represented by Oxyethira sp., Neotrichia sp., Metrichia sp., Helichopsyche sp. (Trichoptera), Miroculis sp., Hagenulopsis sp., Farrodes sp. and Askola sp. (Ephemeroptera) (Tab. 3).

\section{DISCUSSION}

\section{Organic matter input}

The total litter fall input in this transition system (360 to $365 \mathrm{~g} \mathrm{~m}^{-2}$ year-1) was higher than other savanna sys-

Tab. 2. Results from RM-ANOVA and contrast analyses $(\mathrm{P}<0.05)$ for organic matter categories (total OM, leaves, branches, flowers and fruits $(\mathrm{Fl}+\mathrm{Fr})$, and miscellaneous), percentage of remaining mass, and relative abundances of shredders and scrapers individually and summed $(\mathrm{Sh}+\mathrm{Sc})$ in the Boleiras stream.

\begin{tabular}{|c|c|c|c|c|c|}
\hline & DF & SS $\%$ & $\mathbf{F}$ & $\mathbf{P}$ & Contrast analysis \\
\hline $\begin{array}{l}\text { Total organic matter } \\
\text { Error } \\
\text { Month } \\
\text { Residual }\end{array}$ & $\begin{array}{c}1 \\
10 \\
43\end{array}$ & $\begin{array}{c}0.2 \\
21.6 \\
78.3\end{array}$ & 4.161 & $<0.01$ & $\mathrm{M}<$ September $=$ October $=$ November \\
\hline $\begin{array}{l}\text { Leaves } \\
\text { Error } \\
\text { Month } \\
\text { Residual }\end{array}$ & $\begin{array}{c}1 \\
10 \\
43\end{array}$ & $\begin{array}{c}0.1 \\
37.2 \\
62.7\end{array}$ & 8.996 & $<0.01$ & $\mathrm{M}<$ April $=$ September $=$ October \\
\hline $\begin{array}{l}\text { Branches } \\
\text { Error } \\
\text { Month } \\
\text { Residual }\end{array}$ & $\begin{array}{c}1 \\
10 \\
43\end{array}$ & $\begin{array}{c}0.1 \\
19.4 \\
80.5\end{array}$ & 3.667 & $<0.01$ & $\mathrm{M}<$ November \\
\hline $\begin{array}{l}\mathrm{Fl}+\mathrm{Fr} \\
\text { Error } \\
\text { Month } \\
\text { Residual } \\
\end{array}$ & $\begin{array}{c}1 \\
10 \\
43\end{array}$ & $\begin{array}{c}2.2 \\
18.0 \\
79.8\end{array}$ & 3.405 & $<0.01$ & $\mathrm{M}<$ May \\
\hline $\begin{array}{l}\text { Miscellaneous } \\
\text { Error } \\
\text { Month } \\
\text { Residual }\end{array}$ & $\begin{array}{c}1 \\
10 \\
43\end{array}$ & $\begin{array}{c}0.1 \\
7.8 \\
92.0\end{array}$ & 1.304 & 0.233 & \\
\hline $\begin{array}{l}\text { Remaining mass } \\
\text { Error } \\
\text { Month } \\
\text { Residual }\end{array}$ & $\begin{array}{c}1 \\
8 \\
35\end{array}$ & $\begin{array}{c}5.6 \\
21.4 \\
73.0\end{array}$ & 3.412 & $<0.01$ & May $<$ M $<$ November $=$ December $=$ August \\
\hline $\begin{array}{l}\text { Shredders } \\
\text { Error } \\
\text { Month } \\
\text { Residual }\end{array}$ & $\begin{array}{c}2 \\
8 \\
34\end{array}$ & $\begin{array}{c}0.9 \\
18.0 \\
81.1\end{array}$ & 3.019 & $<0.01$ & $\mathrm{M}<$ August $=$ November \\
\hline $\begin{array}{l}\text { Scrapers } \\
\text { Error } \\
\text { Month } \\
\text { Residual }\end{array}$ & $\begin{array}{c}2 \\
8 \\
34\end{array}$ & $\begin{array}{c}7.8 \\
13.7 \\
78.5\end{array}$ & 2.376 & 0.02 & $\mathrm{M}<$ July \\
\hline $\begin{array}{l}\mathrm{Sh}+\mathrm{Sc} \\
\text { Error } \\
\text { Month } \\
\text { Residual }\end{array}$ & $\begin{array}{c}2 \\
8 \\
34\end{array}$ & $\begin{array}{c}8.1 \\
11.9 \\
80.0\end{array}$ & 2.03 & 0.04 & $\mathrm{M}<$ November \\
\hline
\end{tabular}

$D F$, degrees of freedom; SS\%, sums of squares; $M$, other months. 
tems (288 to $336 \mathrm{~g} \mathrm{~m}^{-2}$ year $^{-1}$ in Gonçalves et al., 2006a; França et al., 2009; Gonçalves and Callisto, 2013; Rezende et al., 2016), but lower than typically found in tropical rainforests (113 to $2812 \mathrm{~g} \mathrm{~m}^{-2}$ year ${ }^{-1}$ in Abelho, 2001; Chara et al., 2007; Gregório et al., 2007; Zhou et al., 2007; Alvarez et al., 2009; Cogo and Santos, 2013; Lisboa et al., 2014). Savanna systems (e.g., the Cerrado) and tropical rainforests (e.g., Atlantic forest and the Amazon forest) have a different precipitation range, which explains the differences in productivity (Gonçalves and Callisto, 2013; Gonçalves et al., 2014a). Therefore, the transition zone between Cerrado and Atlantic forest, as in this study area, may have intermediate patterns in plant productivity in riparian zones.

Total CPOM in the litterfall was seasonal, with peaks in dry and rainy season. Leaves were the highest fraction in of CPOM, as shown in other tropical studies (Wantzen et al., 2008; Alvarez et al., 2009; Chave et al., 2010; Tank et al., 2010; Zhang et al., 2014; Rezende et al., 2016). The higher leaf biomass and total CPOM in the transition period is also consistent with other studies of savanna (Gonçalves et al., 2006a; Gonçalves and Callisto, 2013; Rezende et al., 2016) and other Brazilian tropical systems (Gregório et al., 2007; França et al., 2009; Gonçalves et al., 2014a). This leaf senescence is triggered by desiccation due to water stress, and explains the higher CPOM input from August to November (Campanella and Bertiller, 2008). Leaf renewal can also be stimulated by mechanical removal by the first rains (Larned, 2000; Rezende et al., 2016). Input of branches (the second highest CPOM) in November also indicates greater mechanical removal by rainfall and associated winds (Vanschaik et al., 1993; Gonçalves et al., 2014a).

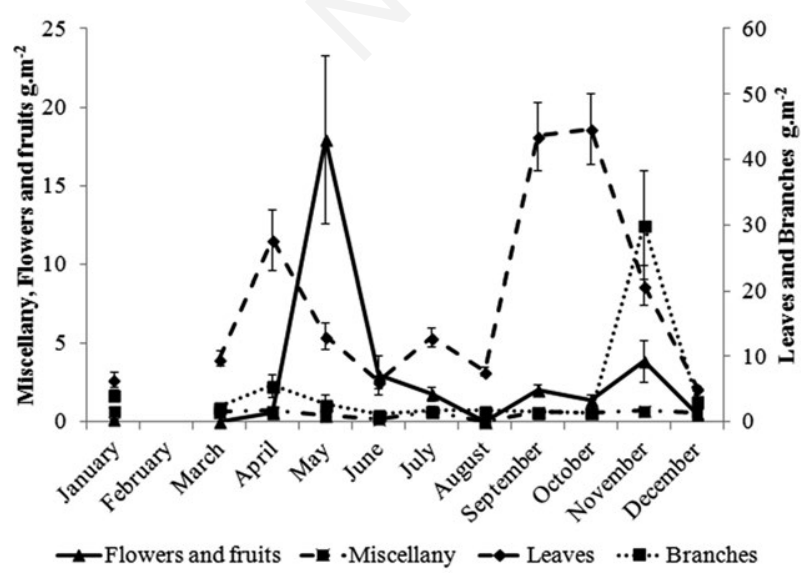

Fig. 2. Monthly values (mean $\pm \mathrm{SE}$ ) for flowers and fruits, miscellaneous organic matter, leaves, and branches in vertical input from the riparian vegetation into the Boleiras stream (January through December 2012).
The novelty in litterfall refers to high leaf litter input also in April, which has not observed in other savanna systems (Gonçalves et al., 2006a; Gonçalves and Callisto, 2013; Rezende et al., 2016) or other Brazilian biomes (Gregório et al., 2007; França et al., 2009; Gonçalves et al., 2014a). Riparian vegetation is an ecotone that serves as an ecological corridor among biomes, and the species composition includes that of the adjacent systems (Wantzen et al., 2008; Gonçalves and Callisto, 2013). Thus, the ecotone characteristics of the riparian zones are highlighted due to geographical proximity (transition system) of this savanna stream to the Atlantic forest biome. The input peak in April may also be a phenological response of one specific species that was not observed in previous studies (Gonçalves and Callisto, 2013). This phenological response may also explain the increase in flower and fruit biomass in May, due to lower rainfall and less physical damage to plant parts associated with germination. We can also conclude that phenological and seasonal factors drive CPOM input from transition riparian vegetation.

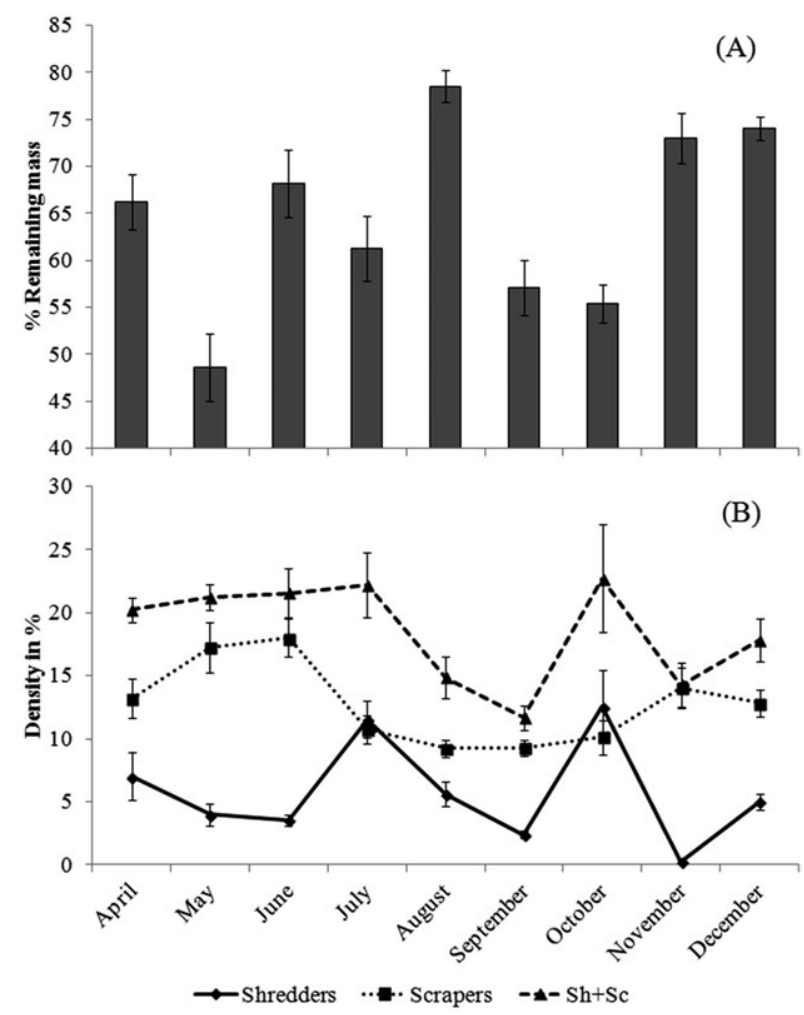

Fig. 3. Monthly values (mean $\pm \mathrm{SE}$ ) for the remaining mass percentage (A), as well as the density of shredders and scrapers individually and summed $(\mathrm{Sh}+\mathrm{Sc}$; B) colonizing the leaf litter in the Boleiras stream (April to December 2012). 
Tab. 3. List of the relative abundance (RA), functional trophic group (FTG), order, family, and genus of the benthic invertebrate community associated with leaf litter in the Boleiras stream (April to December 2012).

\begin{tabular}{|c|c|c|c|c|}
\hline Order & Family & Family / Genus & FTG & $\mathbf{R A}$ \\
\hline \multirow[t]{2}{*}{ Coleoptera } & Psephenidae & Psephenus sp. (L) & $\mathrm{Sc}$ & 0.081 \\
\hline & Staphylinidae & Bledius sp. (L) & $\operatorname{Pr}$ & 0.027 \\
\hline \multirow[t]{2}{*}{ Crustacean } & Amphipod & Dogielinotidae/Hyalella sp. (L) & Sh & 0.054 \\
\hline & Cladocera & Bosminidae/Bosmina sp. (L) & $\mathrm{Fc}$ & 0.243 \\
\hline \multirow[t]{10}{*}{ Diptera } & Ceratopogonidae & Atrichopogon sp. (L) & $\operatorname{Pr}$ & 0.269 \\
\hline & & Bezzia sp. (L) & $\operatorname{Pr}$ & 0.647 \\
\hline & & Probezzia sp. (L) & $\operatorname{Pr}$ & 0.296 \\
\hline & & Sphaeromias sp. (L) & $\operatorname{Pr}$ & 0.350 \\
\hline & Chironomidae & Chironominae (L) & $\mathrm{Gc}$ & 0.052 \\
\hline & & Orthocladiinae (L) & $\mathrm{Gc} / \mathrm{Sc}$ & 0.044 \\
\hline & & Stenochironomus sp. (L) & Sh & 3.530 \\
\hline & & Tanypodinae (L) & $\operatorname{Pr}$ & 0.066 \\
\hline & Empididae & Hemerodromia sp. (L) & $\operatorname{Pr}$ & 0.620 \\
\hline & Simullidae & Chirostilbia sp. (L) & $\mathrm{Fc}$ & 6.818 \\
\hline \multirow[t]{12}{*}{ Ephemeroptera } & Baetidae & Cloeodes sp. (L) & $\mathrm{Sc}$ & 5.039 \\
\hline & & Paracloeodes sp. (L) & $\mathrm{Gc}$ & 0.620 \\
\hline & Euthyplociidae & Campylocia sp. (L) & $\mathrm{Gc}$ & 0.081 \\
\hline & Leptohyphidae & Leptohyphes sp. (L) & $\mathrm{Gc}$ & 2.371 \\
\hline & & Leptohyphidae sp1 & $\mathrm{Gc}$ & 5.335 \\
\hline & & Traveryphes sp. (L) & $\mathrm{Gc}$ & 19.671 \\
\hline & & Tricorythodes sp. (L) & $\mathrm{Gc}$ & 6.791 \\
\hline & & Tricorythopsis sp. (L) & $\mathrm{Gc}$ & 14.605 \\
\hline & Leptophlebiidae & Askola sp. (L) & $\mathrm{Sc}$ & 0.135 \\
\hline & & Farrodes sp. (L) & $\mathrm{Sc}$ & 0.269 \\
\hline & & Hagenulopsis sp. (L) & $\mathrm{Sc}$ & 0.269 \\
\hline & & Miroculis sp. (L) & $\mathrm{Sc}$ & 0.189 \\
\hline Hemiptera & Naucoridae & Limnocoris sp. (L) & $\operatorname{Pr}$ & 0.081 \\
\hline Megaloptera & Corydalidae & Corydalus sp. (L) & $\operatorname{Pr}$ & 0.081 \\
\hline \multirow[t]{8}{*}{ Odonata } & Gomphidae & Phyllogomphoides sp (L) & $\operatorname{Pr}$ & 0.054 \\
\hline & Libellulidae & Elasmothemis sp. (L) & $\operatorname{Pr}$ & 0.027 \\
\hline & Calopterygidae & Hetaerina sp. (L) & $\operatorname{Pr}$ & 0.377 \\
\hline & Coenagrionidae & Acanthagrion sp. (L) & $\operatorname{Pr}$ & 0.323 \\
\hline & Gomphidae & Phyllogomphoides sp (L) & $\operatorname{Pr}$ & 0.054 \\
\hline & Libellulidae & Elasmothemis sp. (L) & $\operatorname{Pr}$ & 0.027 \\
\hline & & Macrothemis sp. (L) & $\operatorname{Pr}$ & 0.108 \\
\hline & Perilestidae & Perilestes sp. (L) & $\operatorname{Pr}$ & 0.377 \\
\hline \multirow[t]{3}{*}{ Plecoptera } & Grypopterygidae & Paragripopteryx sp. (L) & Sh & 6.117 \\
\hline & & Tupiperla sp. (L) & Gc & 3.880 \\
\hline & Perlidae & Anacroneuria sp. (L) & $\operatorname{Pr}$ & 0.781 \\
\hline \multirow[t]{17}{*}{ Trichoptera } & Calamoceratidae & Phylloicus sp. (L) & Sh & 1.240 \\
\hline & Helicopsychidae & Helichopsyche sp. (L) & $\mathrm{Sc}$ & 0.189 \\
\hline & Hydrobiosidae & Atopsyche sp. (L) & $\operatorname{Pr}$ & 0.027 \\
\hline & Hydropsychidae & Leptonema sp. (L) & $\mathrm{Fc}$ & 3.099 \\
\hline & & Smicridea sp. (L) & $\mathrm{Fc}$ & 2.452 \\
\hline & Hydroptilidae & Metrichia sp. (L) & $\mathrm{Sc}$ & 0.216 \\
\hline & & Neotrichia sp. (L) & $\mathrm{Sc}$ & 0.350 \\
\hline & & Oxyethira sp. (L) & $\mathrm{Sc}$ & 6.252 \\
\hline & Leptoceridae & Nectopsyche sp. (L) & $\mathrm{Gc} / \mathrm{Sh}$ & 0.108 \\
\hline & & Notalina sp. (L) & Sh & 0.808 \\
\hline & & Oecetis sp. (L) & $\operatorname{Pr}$ & 0.054 \\
\hline & & Triplectides sp. (L) & Sh & 0.189 \\
\hline & Odontoceridae & Marilia sp. (L) & Sh & 0.835 \\
\hline & Philopotamidae & Wormaldia sp. (L) & $\mathrm{Fc}$ & 0.620 \\
\hline & Polycentropodidae & Cyrnellus sp. (L) & $\mathrm{Fc}$ & 0.512 \\
\hline & & Polycentropus sp. (L) & $\mathrm{Fc} / \mathrm{Pr}$ & 0.728 \\
\hline & & Polyplectropus sp. (L) & $\mathrm{Fc}$ & 0.862 \\
\hline
\end{tabular}

Gc, gathering-collectors; Fc, filtering-collectors; Sh, shredders; Sc, scrapers; Pr, predators. 


\section{Leaf litter breakdown rates}

The peak in leaf litter breakdown in May (beginning of dry season) contrasts that observed in others savanna streams, which typically peak in summer season (December to February) (Sales et al., 2015; Rezende et al., 2016). This result may be explained by the peak in high energy resources such as flowers and fruits (Gonçalves et al., 2006a; França et al., 2009; Gonçalves and Callisto, 2013), as an increase in flower and fruit input can promote environmental enrichment and accelerate leaf litter breakdown (Gonçalves et al., 2014b; Alvim et al., 2015a, 2015b). The input of higher-quality organic matter (e.g., flowers and fruits, leaf litter species with high concentrations of nutrients such as nitrogen and phosphorus) can increase the density of decomposers (Ferreira et al., 2014; Cornut et al., 2015; Graça et al., 2015), which consequently consume the lower-quality organic matter (e.g., leaf litter with high concentrations of secondary and structural compounds). These results are the first to indicate flowers and fruits as potential influence in nutrient dynamics tropical streams.

Leaf litter breakdown rates $\left(k \sim 0.016\right.$ day $\left.^{-1}\right)$ show an upper range comparable to other savanna streams $(0.007$ to 0.016 day $^{-1}$ in Gonçalves et al., 2006b; Gonçalves et al., 2007; Moretti et al., 2007a; Gonçalves et al., 2012b), and were classified as 'fast' for tropical systems according to Gonçalves et al. (2014b). However, shredders were not associated with leaf litter breakdown rates. On the other hand, the remaining mass showed a positive relationship with water flow (due to rainfall increase), possibly through physical abrasion (Rezende et al., 2014). The lower abundance of shredders with increased water flow and litter breakdown can be explained by the washing force, which decreases colonization by invertebrates (Ferreira and Graça, 2006; Rezende et al., 2014). Finally, the higher activity of scrapers compared to shredders in the current study generally agrees with results of other studies in savanna streams (Gonçalves et al., 2006b; Moretti et al., 2007a). Scrapers can promote the fragmentation of plant tissue by scraping the periphyton growing on the substrate (Gonçalves et al., 2006b).

The density ( 2 to 780 individuals..$^{-1}$ in Moretti et al., 2007a; Ligeiro et al., 2010; Gonçalves et al., 2012a; Gonçalves et al., 2012b; Rezende et al., 2016) and average richness of invertebrates ( 1 to 22 taxa in Moretti et al., 2007b; Alvim et al., 2015b; Rezende et al., 2016) at our site was low compared to other savanna streams. The most abundant taxa were Tanypodinae, Chironominae, and Orthocladiinae, belonging to the family Chironomidae (Diptera). The dominance of Chironomidae is typical in tropical and temperate streams (Milošević et al., 2012; Biasi et al., 2013; Uieda and Carvalho, 2015) due to their high adaptive capacity for various environmental conditions (Anderson and Ferrington, 2012; Milošević et al.,
2012). The low abundance of shredders (higher in August and November) and scrapers is also typical of tropical streams (Boyero et al., 2011, 2012).

\section{CONCLUSIONS}

The total CPOM (productivity) input in the transition riparian zone was higher than that of other savanna systems, but lower than typical for Atlantic forest; this supports our first hypothesis. The CPOM also shows peaks in the transition period (from dry to rainy season) in response to water stress, supporting our second hypothesis. The higher leaf litter breakdown in May can be explained by the peak in input of higher-quality organic matter (flowers and fruits). The positive relationship between the remaining mass and water flow corroborates our third hypothesis (by increase of physical abrasion). Therefore, assuming that climate factors (e.g., rainfall) directly affect the input and quality of CPOM and leaf litter breakdown rates, changes in the climate can alter functioning of savanna streams. The transition riparian zone (e.g. savanna and rainforest) show intermediate patterns of plant productivity and leaf processing in tropical zones. Leaf litter breakdown was driven by environmental enrichment, indicating that changes in the savanna riparian composition may also alter ecosystem function.

\section{ACKNOWLEDGMENTS}

Financial support was provided by CNPq, CAPES, FADENOR and FAPEMIG. We thank the Postgraduate Program in Ecology and Conservation at the Federal Rural University of the Semi-arid Region.

\section{REFERENCES}

Abelho M, 2001. From litterfall to breakdown in streams: a review. Sci. World J. 1:656-680.

Allan JD, 2004. Landscapes and riverscapes: The influence of land use on stream ecosystems. Annu. Rev. Ecol. Evol. Syst. 35:257-284.

Allan JD, Castillo MM, 2007. Stream ecology: structure and function of running waters. Springer, Dordrecht: $436 \mathrm{pp}$.

Allan K, Boyero L, Pearson RG, 2009. Chemical communication in competitive interactions among tropical stream detritivores. Trop. Zool. 22:195-204.

Alvarez JA, Villagra PE, Rossi BE, Cesca EM, 2009. Spatial and temporal litterfall heterogeneity generated by woody species in the Central Monte desert. Plant Ecology 205:295-303.

Alvim EACC, De Oliveira Medeiros A, Rezende RS, Gonçalves JF, 2015a. Small leaf breakdown in a Savannah headwater stream. Limnologica 51:131-138.

Alvim EACC, Medeiros AO, Rezende RDS, Júnior JFG, 2015b. Leaf breakdown in a natural open tropical stream. J. Limnol. 74:248-260. 
Anderson AM, Ferrington LC, 2012. Resistance and resilience of winter-emerging Chironomidae (Diptera) to a flood event: implications for Minnesota trout streams. Hydrobiologia 707:59-71.

Bärlocher F, Graça MAS, 2005. Total phenolics, p. 97-100. In: M.A.S. Graça, F. Barlocher and M.O. Gessner (eds.), Methods to study litter decomposition. Springer.

Biasi C, Tonin AM, Restello RM, Hepp LU, 2013. The colonisation of leaf litter by Chironomidae (Diptera): The influence of chemical quality and exposure duration in a subtropical stream. Limnologica 43:427-433.

Boyero L, Pearson RG, Dudgeon D, Ferreira V, Graça MAS, Gessner MO, Boulton AJ, Chauvet E, Yule CM, Albariño RJ, Ramírez A, Helson JE, Callisto M, Arunachalam M, Chará J, Figueroa R, Mathooko JM, Gonçalves JF Jr, Moretti MS, Chará-Serna AM, Davies JN, Encalada A, Lamothe S, Buria LM, Castela J, Cornejo A, Li AOY, M'erimba C, Villanueva VD, Del Carmen Zúñiga M, Swan CM, Barmuta LA, 2012. Global patterns of stream detritivore distribution: implications for biodiversity loss in changing climates. Glob. Ecol. Biogeogr. 21:134-141.

Boyero L, Pearson RG, Dudgeon D, Graça MAS, Gessner MO, Albarino RJ, Ferreira V, Yule CM, Boulton AJ, Arunachalam M, Callisto M, Chauvet E, Ramirez A, Chara J, Moretti MS, Goncalves JF Jr, Helson JE, Chara-Serna AM, Encalada AC, Davies JN, Lamothe S, Cornejo A, Li AOY, Buria LM, Villanueva VD, Zuniga MC, Pringle CM, 2011. Global distribution of a key trophic guild contrasts with common latitudinal diversity patterns. Ecology 92:1839-1848.

Campanella MV, Bertiller MB, 2008. Plant phenology, leaf traits and leaf litterfall of contrasting life forms in the arid Patagonian Monte, Argentina. J. Veg. Sci. 19:75-85.

Campbell IC, James KR, Hart BT, Devereaux A, 1992. Allochthonous coarse particulate organic material in forest and pasture reaches of two south-eastern Australian streams. Freshwater Biol. 27:353-365.

Chara J, Baird D, Telfer T, Giraldo L, 2007. A comparative study of leaf breakdown of three native tree species in a slowlyflowing headwater stream in the Colombian Andes. Int. Rev. Hydrobiol. 92:183-198.

Chave J, Navarrete D, Almeida S, Álvarez E, Aragão LEOC, Bonal D, Châtelet P, Silva-Espejo JE, Goret J-Y, Hildebrand PV, Jiménez E, Patiño S, Peñuela MC, Phillips OL, Stevenson P, Malhi Y, 2010. Regional and seasonal patterns of litterfall in tropical South America. Biogeosciences 7:43-55.

Cheshire K, Boyero L, Pearson RG, 2005. Food webs in tropical Australian streams: shredders are not scarce. Freshwater Biol. 50:748-769.

Cogo GB, Santos S, 2013. The role of aeglids in shredding organic matter in neotropical streams. J. Crust. Biol. 33:519-526.

Cornut J, Ferreira V, Gonçalves AL, Chauvet E, Canhoto C, 2015. Fungal alteration of the elemental composition of leaf litter affects shredder feeding activity. Freshwater Biol. 60:1755-1771.

Crawley MJ, 2007. The R Book. J. Wiley \& Sons Ltd., Chichester: $950 \mathrm{pp}$.

Cummins K, Merritt R, Andrade P, 2005. The use of invertebrate functional groups to characterize ecosystem attributes in selected streams and rivers in south Brazil. Stud. Neotrop. Fauna Environ. 40:69-89.
Ferreira V, Castagneyrol B, Koricheva J, Gulis V, Chauvet E, Graca MA, 2014. A meta-analysis of the effects of nutrient enrichment on litter decomposition in streams. Biol. Rev. 90:669-688.

Ferreira V, Graça MAS, 2006. Do invertebrate activity and current velocity affect fungal assemblage structure in leaves? Int. Rev. Hydrobiol. 91:1-14.

França JS, Gregorio RS, De Paula JDA, Gonçalves JF Jr, Ferreira FA, Callisto M, 2009. Composition and dynamics of allochthonous organic matter inputs and benthic stock in a Brazilian stream. Mar. Freshwater Res. 60:990-998.

Gessner MO, Chauvet E, Dobson M, 1999. A perspective on leaf litter reakdown in streams. Oikos 85:377-384.

Gessner MO, Swan CM, Dang CK, Mckie BG, Bardgett RD, Wall DH, Hattenschwiler S, 2010. Diversity meets decomposition. Trends Ecol. Evol. 25:372-380.

Gonçalves JF Jr, De Souza Rezende R, Gregório RS, Valentin GC, 2014a. Relationship between dynamics of litterfall and riparian plant species in a tropical stream. Limnologica 44:40-48

Gonçalves JF Jr, Graça MAS, Callisto M, 2007. Litter decomposition in a Cerrado savannah stream is retarded by leaf toughness, low dissolved nutrients and a low density of shredders. Freshwater Biol. 52:1440-1451.

Gonçalves JF Jr, Rezende RS, França J, Callisto M, 2012a. Invertebrate colonisation during leaf processing of native, exotic and artificial detritus in a tropical stream. Mar. Freshwater Res. 63:428-439.

Gonçalves JF Jr, Rezende RS, Martins NM, Gregorio RS, 2012b. Leaf breakdown in an Atlantic Rain Forest stream. Austral Ecol. 37:807-815.

Gonçalves JF Jr, Martins RT, Ottoni BMP, Couceiro SRM, 2014b. [Uma visão sobre a decomposição foliar em sistemas aquáticos brasileiros], p. 89-116. In: N. Hamada, J.L. Nessimian and R.B. Querino (eds.), [Insetos aquáticos: biologia, ecologia e taxonomia].[Book in Portuguese]. Instituto Nacional de Pesquisas da Amazônia, Manaus.

Gonçalves JF Jr, Callisto M, 2013. Organic-matter dynamics in the riparian zone of a tropical headwater stream in Southern Brasil. Aquatic Bot. 109:8-13.

Gonçalves JF Jr, França JS, Callisto M, 2006a. Dynamics of allochthonous organic matter in a tropical Brazilian headstream. Braz. Arch. Biol. Techn. 49:967-973.

Gonçalves JF Jr, França JS, Medeiros AO, Rosa CA, Callisto M, 2006b. Leaf breakdown in a tropical stream. Int. Rev. Hydrobiol. 91:164-177.

Graça MAS, 2001. The role of invertebrates on leaf litter decomposition in streams - a review. Int. Rev. Hydrobiol. 86:383-393.

Graça MAS, Bärlocher F, 2005. Radial diffusion assay for tannins, p. 121-128. In: M.A.S. Graça, F. Bärlocher and M.O. Gessner (eds.), Methods to study litter decomposition: A practical guide. Springer, Dordrecht.

Graça MAS, Ferreira V, Canhoto C, Encalada AC, Guerrero-Bolaño F, Wantzen KM, Boyero L, 2015. A conceptual model of litter breakdown in low order streams. Int. Rev. Hydrobiol. 100:1-12.

Graça MAS, Hyde K, Chauvet E, 2016. Aquatic hyphomycetes and litter decomposition in tropical - subtropical low order streams. Fungal Ecol. 19:182-189. 
Gregório RS, Valentin G, Ferreira FA, Aleixo LA, França JS, Gonçalves JF Jr, Callisto M, Batista ML, Gaspar RDO, Rodello CM, 2007. [Contribuição foliar alóctone de espécies vegetais num córrego de $2^{\mathrm{a}}$ ordem na Estação Ambiental de Peti (CEMIG) - MG].[Article in Portuguese]. Rev. Bras. Biocienc. 5:33-35.

Hamada N, Nessimian JL, Querino RB, 2014. [Insetos aquáticos na Amazônia brasileira: taxonomia, biologia e ecologia].[Book in Portuguese]. Instituto Nacional de Pesquisas da Amazônia, Manaus: 724 pp.

Larned ST, 2000. Dynamics of coarse riparian detritus in a Hawaiian stream ecosystem: a comparison of drought and postdrought conditions. J. N. Am. Benthol. Soc. 19:215-234.

Ligeiro R, Moretti MS, Gonçalves JF Jr, Callisto M, 2010. What is more important for invertebrate colonization in a stream with low-quality litter inputs: exposure time or leaf species? Hydrobiologia 654:125-136.

Lisboa LK, Silva ALD, Siegloch A, Junior JG, Petrucio M, 2014. Temporal dynamics of allochthonous coarse particulate organic matter in a subtropical Atlantic Rainforest Brazilian stream. Mar. Freshwater Res. 66:674-680.

Merritt RW, Cummins KW, 1996. An introduction to the aquatic insects of North America. Kendall/Hunt Publishing Co., Dubuque: 862 pp.

Milošević D, Simić V, Stojković M, Čerba D, Mančev D, Petrović A, Paunović M, 2012. Spatio-temporal pattern of the Chironomidae community: toward the use of non-biting midges in bioassessment programs. Aquat. Ecol. 47:37-55.

Moretti M, Gonçalves JJF, Callisto M, 2007a. Leaf breakdown in two tropical streams: Differences between single and mixed species packs. Limnologica 37:250-258.

Moretti MS, Gonçalves JJF, Ligeiro R, Callisto M, 2007b. Invertebrates colonization on native tree leaves in a neotropical stream (Brazil). Int. Rev. Hydrobiol. 92:199-210.

Naiman RJ, Decamps H, 2005. Biophysical connectivity and riparian functions, p. 159-187. In: R.J. Naiman, H. Décamps and M.E. McClain (eds.), Riparia - Ecology, conservation, and management of streamside communities. Elsevier, Amsterdam.

Pérez GP, 1988. [Guía para el studio de los macroinvertebrados acuáticos del departamento de Antioquia].[Book in Spanish]. Editorial Presencia Ltda., Bogotà: 217 pp.
Rezende RDS, Graça MaS, Santos AM, Medeiros AO, Santos PF, Nunes YR, Junior JFG, 2016. Organic matter dynamics in a tropical gallery forest in a grassland landscape. Biotropica 48:301-310.

Rezende RDS, Leite GFM, De-Lima AKS, Silva Filho LaBD, Chaves CVC, Prette ACH, Freitas JS, Gonçalves Júnior JF, 2015. Effects of density and predation risk on leaf litter processing by Phylloicus sp. Austral Ecol. 40:693-700.

Rezende RS, Petrucio MM, Gonçalves JF Jr, 2014. The effects of spatial scale on breakdown of leaves in a tropical watershed. Plos One 9:e97072.

Sales MA, Goncalves JF Jr, Dahora JS, Medeiros AO, 2015. Influence of leaf quality in microbial decomposition in a headwater stream in the Brazilian Cerrado: A 1-year study. Microbial Ecol. 69:84-94.

Tank JL, Rosi-Marshall EJ, Griffiths NA, Entrekin SA, Stephen ML, 2010. A review of allochthonous organic matter dynamics and metabolism in streams. J. N. Am. Benthol. Soc. 29:118-146.

Uieda V, Carvalho E, 2015. Experimental manipulation of leaf litter colonization by aquatic invertebrates in a third order tropical stream. Rev. Bras. Biol. 75:405-413.

Vanschaik CP, Terborgh JW, Wright SJ, 1993. The phenology of tropical forests: Adaptive significance and consequences for primary consumers. Annu. Rev. Ecol. Syst. 4:353-377.

Wantzen KM, Wagner R, 2006. Detritus processing by invertebrate shredders: a neotropical-temperate comparison. J. N. Am. Benthol. Soc. 25:216-232.

Wantzen KM, Yule CM, Mathooko JM, Pringle C, 2008. Organic matter processing in tropical streams, p. 43-64. In: D. Dudgeon (ed.), Tropical stream ecology. Elsevier, Amsterdam.

Webster JR, Meyer JL, 1997. Organic matter budgets for stream: a synthesis. In: J.R. Webster and J.L. Meyer (eds.), Stream organic matter budgets. J. N. Am. Benthol. Soc. 16:3-161.

Zhang H, Yuan W, Dong W, Liu S, 2014. Seasonal patterns of litterfall in forest ecosystem worldwide. Ecol. Complex. 20:240-247.

Zhou G, Guan L, Wei X, Zhang D, Zhang Q, Yan J, Wen D, Liu J, Liu S, Huang Z, Kong G, Mo J, Yu Q, 2007. Litterfall production along successional and altitudinal gradients of subtropical monsoon evergreen broadleaved forests in Guangdong, China. Plant Ecol. 188:77-89. 